\title{
Green Fodder Production Potential of Oat cv. Kent under Semi-arid Climatic Conditions of Tonk-Rajasthan in Frontline Demonstration
}

\author{
Gitam Singh $^{1}$, R.B. Sharma ${ }^{2}$ and Mahendra Singh $^{3}$ \\ ${ }^{1}$ Krishi Vigyan Kendra, Tonk, Rajasthan - 304022, India \\ ${ }^{2}$ National Agricultural Higher Education Project (ICAR), KB-II, New Delhi - 110011, India \\ ${ }^{3}$ Krishi Vigyan Kendra, Borkhera, Kota - 324001, India \\ *Corresponding author
}

\section{A B S T R A C T}

\section{Keywords}

Climatic conditions, FLD, Green fodder, Oat, Kent, Yield

Article Info

Accepted:

24 February 2017

Available Online:

10 March 2017
Oats are grown for use as grain as well as forage and fodder, straw for bedding, hay, haylage, silage and chaff. The study was conducted at different villages of Tonk district of Rajasthan. The seed of Kent variety of Oat were provided from Central Sheep and Wool Research Institute, Avikanagar, Tonk, Rajasthan for the study of comparison with local varieties. Among the different sites green fodder production of Diggi village of Mlapura was lowest $(166.7 \mathrm{q} / \mathrm{ha})$ because of poor quality of soil but production of Banasthali village trial was excellent $(231.4 \mathrm{q} / \mathrm{ha})$ because of fertile soil and good availability of water. At KVK farm trial average production (199.2 q/ha) of green fodder was noted which slightly poor in comparison with other trials due to poor soil fertility and insufficient water availability. The production potential irrespective of trial sites was higher in oat fodder variety Kent. It can be concluded from the total production of green fodder that the major variation was found due to environment and improvement might came through the availability of resources.

\section{Introduction}

India sustains about $15 \%$ of the world's livestock population and $17 \%$ of world human population from $2.3 \%$ of world geographical area and $4.2 \%$ of world's water resources (Kumari et al., 2014). Livestock production is backbone of Indian agriculture contributing $7 \%$ to national GDP and source of employment and livelihood for $70 \%$ population in rural areas. India ranks first in terms of milk production (129.7 million tonnes), however, the productivity is quite low mainly because of scarcity of feeds and fodders. Recent reports clearly indicated that India faces a net deficit of green fodder by
$61.1 \%$, dry crop residues by $21.9 \%$ and for feeds as high as 64\% (Kumari et al., 2014). This gap may be narrowed down by cultivating quick growing, high yielding and responsive fodder crops under assured supply of irrigation with adequate fertilisation. There is immense pressure on cultivated land and water resources due to increasing human population, which left us with very limited resources for fodder cultivation.

The oat (Avena sativa), sometimes called the common oat, is a species of cereal grain grown for its seed, which is known by the 
same name (usually in the plural, unlike other cereals and pseudo cereals). While oats are suitable for human consumption as oatmeal and rolled oats, one of the most common uses is as livestock feed. The wild ancestor of Avena sativa and the closely related minor crop, A. byzantina, is the hexaploid wild oat A. sterilis. Genetic evidence shows the ancestral forms of $A$. sterilis grew in the Fertile Crescent of the Near East. Domesticated oats appear relatively late, and far from the Near East, in Bronze Age Europe. Oats, like rye, are usually considered a secondary crop, i.e., derived from a weed of the primary cereal domesticates wheat and barley. As these cereals spread westwards into cooler, wetter areas, this may have favored the oat weed component, and have led to its domestication (Zhou et al., 1999).

Oats are best grown in temperate regions and hence suitable for winter season. Winter oats may be grown as fodder crop. They also can be used for pasture; they can be grazed a while, then allowed to head out for grain production. Oats are generally considered healthy due to their rich content of several essential nutrients. This is an excellent fodder specially during winter seasons.

Performance of oat cultivars has been studied by various workers in different ecological situations. Singh and Singh (1992) evaluated eleven oat cultivar and reported that JHO 811 produced the highest green fodder yield of 55 t ha ${ }^{-1}$ followed by JHO816 (54.3 $\left.\mathrm{t} \mathrm{ha}^{-1}\right)$ and JHO817 (53.9 t ha $^{-1}$ ). Kumar et al. (1992) reported that the variety Kent was superior in fodder yield as compared to local varieties. Bhatti et al., (1992) evaluated thirteen promising cultivars of oats and reported that PD2LV65 and S-81 were superior to all the other cultivars in plant height, tillers per plant, stem thickness, leaves per tillers, leaf area, green fodder yield and dry matter yield. these reports has showed that improved varieties of oats have potential to produce three-fold green fodder i.e. 60-80 $\mathrm{t} \mathrm{ha}^{-1}$ and could feed double the number of animals per unit area as against the traditional fodder crops. The introduction of new high yielding oat varieties, the farmers have recognized oat as important fodder crop for filling the fodder gap. Many cultivars of oat have high feed value if cut at flowering stage i.e., the best time for the crop harvest is at 50 percent flowering stage for better yield and can meet the demand of rapidly growing livestock industry. The farmers face fodder deficiency in winter when they have only dry stalks of cereal fodder or dry summer grasses. Under such conditions adoption of oat production technology can be beneficial for providing fodder for winter seasons. There is a direct need to maximize fodder production per unit area which could be increased 2-3 fold by adopting improved varieties and agronomic practices (Kumar, 2014a,b; 2013; 2012).

\section{Materials and Methods}

The area under this study is Tonk District, Rajasthan, which is located in Eastern part of the state between 75007 ' 00 " $\mathrm{E}$ to 760 19'00" E and $25041^{\prime \prime} 00$ " $\mathrm{N}$ to $26034^{\prime} 00^{\prime \prime}$ $\mathrm{N}$. The total geographical area covered by the District is $7194 \mathrm{~km}^{2}$. The climate of the area is semiarid type. The average annual rainfall of the district is $598 \mathrm{~mm}$. The area is having general flat to undulating topography. The Banas River, $135 \mathrm{kms}$ in length, is major one running through Tonk district. The study was conducted at different villages (Banasthali, KVK Farm, Khidgi, Jagatpura in Newai Tahsil and Diggi in Malpura Tahasil) of Tonk district of Rajasthan. The seed of Kent variety of Oat were provided from Central Sheep and Wool Research Institute, Avikanagar, Tonk, Rajasthan for the study of comparision with local varieties. Four farmers were selected from Newai Tahasil and One farmer was selected from Malpura Tahasil. $8 \mathrm{~kg}$ seed was 
provided to each farmer for the green fodder production.

\section{Results and Discussion}

It is found to see from Table 1 that the green fodder production of Diggi village of Malpura trial was lowest production $(166.7 \mathrm{q} / \mathrm{ha})$ because of poor quality of soil but production of Banasthali village trial was excellent production $(231.4 \mathrm{q} / \mathrm{ha}$ ) because of fertile soil and good availability of water. In the same case green fodder production of local variety was much lower.

Total green fodder production of Khidgi village trial was fairly good $(217.1 \mathrm{q} / \mathrm{ha})$ due to good fertility of soil, good availability of water and proper monitoring of the farm but in the case of Jagatpura village trial it was not proper maintained and insufficient so local variety was also poor production of green fodder.

KVK farm trial was average production (199.2q/ha) of green fodder in comparison with other trials due to soil fertility and insufficient water availability but good agronomical practices affect the production of trial and performance of local variety was not good.

Table.1 Analysis of green fodder production of Kent variety of oat (q/ha)

\begin{tabular}{|c|c|c|c|c|c|c|c|c|}
\hline \multirow[t]{2}{*}{$\begin{array}{l}\text { S. } \\
\text { No. }\end{array}$} & \multirow[t]{2}{*}{ Tahsil } & \multirow[t]{2}{*}{ Village } & \multirow[t]{2}{*}{$\begin{array}{l}\text { Seed } \\
(\mathrm{Kg})\end{array}$} & \multirow{2}{*}{$\begin{array}{l}\text { Area } \\
\text { Covered } \\
\text { (ha) }\end{array}$} & \multicolumn{3}{|c|}{$\begin{array}{l}\text { Green Fodder production } \\
\text { (quintal) }\end{array}$} & \multirow[t]{2}{*}{$\begin{array}{l}\text { Total } \\
\text { production }\end{array}$} \\
\hline & & & & & I time & II time & III time & \\
\hline 1. & Newai & Banasthali & 8 & 0.10 & 112.3 & 72.2 & 46.9 & 231.4 \\
\hline 2. & Newai & KVK Farm & 8 & 0.10 & 96.5 & 61.1 & 41.6 & 199.2 \\
\hline 3. & Newai & Khidgi & 8 & 0.10 & 98.3 & 75.4 & 43.4 & 217.1 \\
\hline 4. & Newai & Jagatpura & 8 & 0.10 & 85.6 & 60.2 & 32.2 & 178.0 \\
\hline 5. & Malpura & Diggi & 8 & 0.10 & 69.3 & 62.9 & 34.5 & 166.7 \\
\hline
\end{tabular}

Table.2 Analysis of green fodder production of local different variety of oat (q/ha)

\begin{tabular}{|l|l|l|l|l|l|l|l|l|}
\hline \multirow{2}{*}{$\begin{array}{l}\text { S. } \\
\text { No. }\end{array}$} & Tahsil & Village & \multirow{2}{*}{$\begin{array}{l}\text { Seed } \\
(\mathrm{Kg})\end{array}$} & & & $\begin{array}{l}\text { Area } \\
\text { Covered } \\
\text { (ha) }\end{array}$ & & \multicolumn{2}{l}{$\begin{array}{l}\text { Green Fodder production } \\
\text { (quintal) }\end{array}$} & Total \\
\cline { 5 - 8 } & & & I time & II time & III time & \\
\hline 1. & Newai & Banasthali & 8 & 0.10 & 73.3 & 33.7 & 29.1 & 136.1 \\
\hline 2. & Newai & KVK Farm & 8 & 0.10 & 78.9 & 32.5 & 23.6 & 135.0 \\
\hline 3. & Newai & Khidgi & 8 & 0.10 & 65.6 & 34.7 & 25.7 & 126.0 \\
\hline 4. & Newai & Jagatpura & 8 & 0.10 & 61.2 & 35.6 & 25.5 & 122.3 \\
\hline 5. & Malpura & Diggi & 8 & 0.10 & 58.2 & 31.9 & 27.3 & 117.4 \\
\hline
\end{tabular}


Fig.1 Performance of varieties for green fodder production
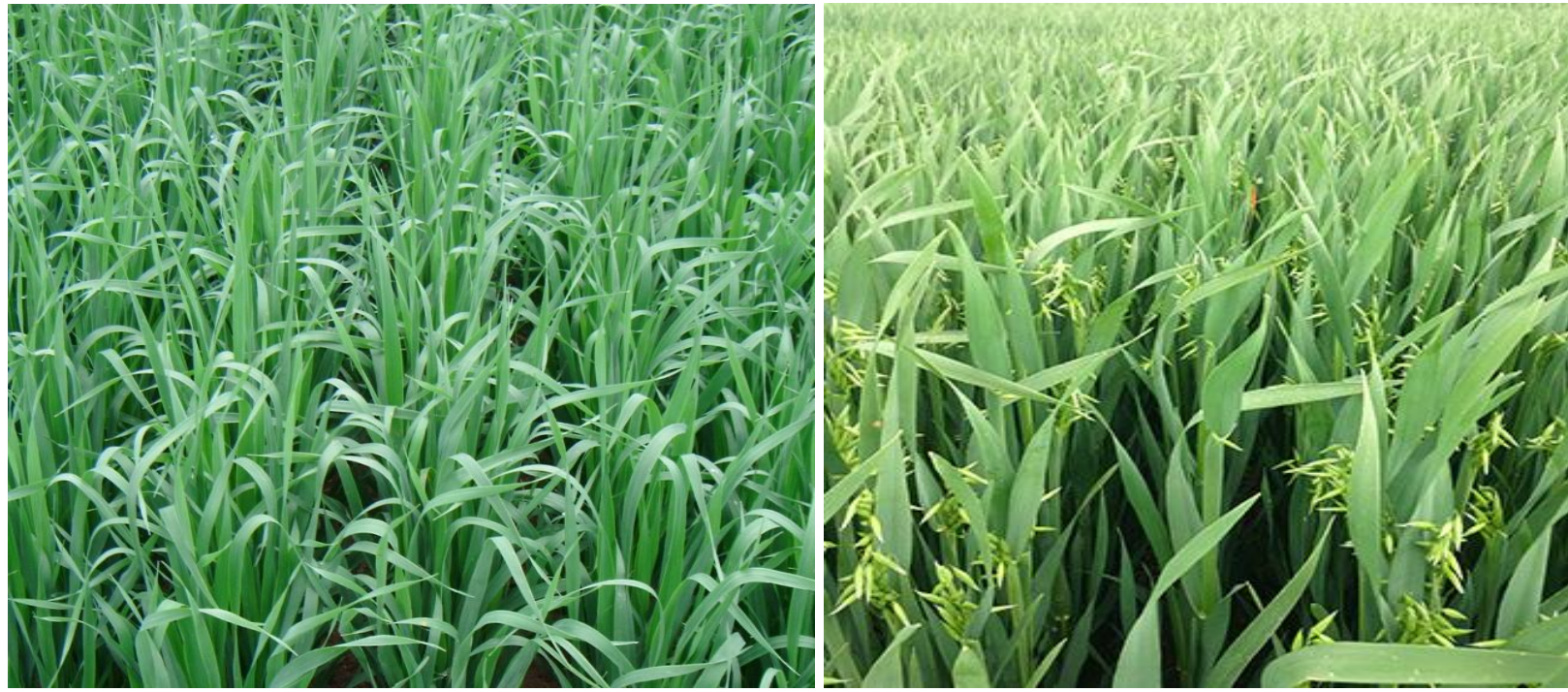

Fig. 2 Monitoring of germination and growth

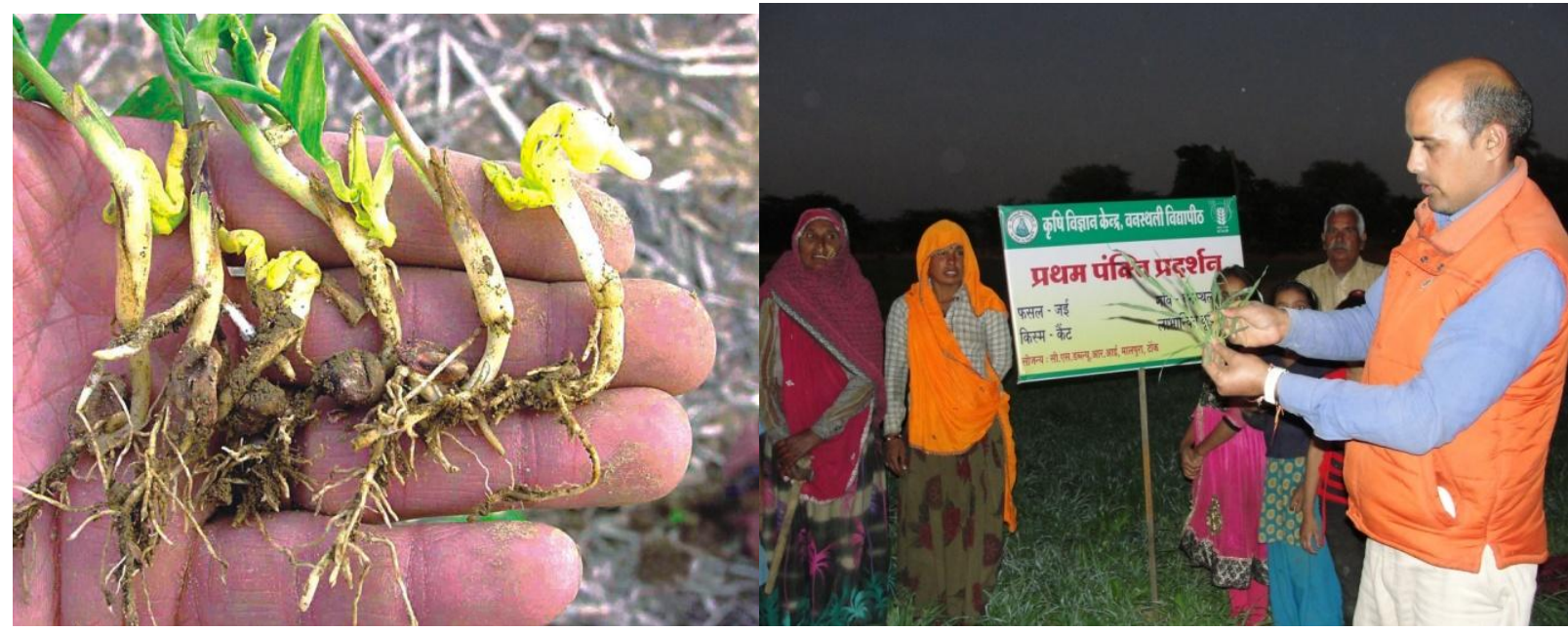

Kim and Seo (1988) also reported that high yielding varieties tended to be upright with broad leaves than low yielding varieties. The variation in leaf area may also be attributed to variation in genetic make-up and adaptability of these varieties to different environmental conditions. Similarly, Ahmad et al. (2008) in his findings explained that the variation in leaf area and other parameters in different varieties at different locations may also be attributed to varying genetic make-up, soil and environmental adaptability.
Our results of this study are fully corroborated with Assefa, 2006 who have reported oat forage average DM yields range from 4 to 15 t/ha, but much higher yields have been obtained.

Total production of green fodder estimates for all the traits were concluded that the major variation was found due to environment and improvement might came through the availability of resources. 


\section{References}

Ahmad, G., M. Ansar, S. Kaleem, G. Nabi and M. Hussain (2008). Performance of early maturing oat (Avena Sativa) cultivars for yield and quality. J. Agric. Res. 46: 341-346.

Assefa, G., 2006. Avena sativa L.. In: Brink, M. and Belay, G. (Editors). PROTA 1: Cereals and pulses/Céréales et légumes secs. [CD-Rom]. PROTA, Wageningen, Netherlands.

Bhatti, M.B., A. Hussain and D. Mohammad, (1992). Fodder production potential of different oat cultivars under two cut system. Pak. J. Agric. Res., 13: 184190.

Kim, D. A. and S. Seo (1988). Comparative study of introduced oats for forage production, growth characteristics and yield of spring oats. Korean J. Anim. Sci. 30: 269-275.

Kumar, A., S.K. Rajpali and D.P. Handa, (1992). Estimation of forage yield in oats (Avena sativa L.) by sampling methods. Crop. Res. (Hisar), 5: 370375.

Kumar, R. (2012) Crop technology demonstration: An effective communication approach for dissemination of sustainable Green Gram production technology. Crop Improvement 39:1583-1584.

Kumar, R. (2013) Evaluation of Crop technology demonstration of mustard crop in Transitional plain of Inland
Drainage Zone of Rajasthan. International Journal of Agricultural and Statistical Sciences 9:657-660.

Kumar, R. (2014a) Assessment of Technology Gap and Productivity Gain through Crop Technology Demonstration in Chickpea. Indian Journal of Agricultural Research 48(2):162-164.

Kumar, R. (2014b) Crop Technology Demonstration: An Effective Communication Approach for Dissemination of Wheat Production Technology. Agricultural Science Digest-A Research Journal 34(2):131134.

Kumari, A; Kumar, P; Ahmad, E; Singh, M; Kumar, Rakesh; Yadav, RK; Datt, C and Chinchmlatpure, A (2014) Fodder Yield and Quality of Oats Fodder (Avena sativa) as Influenced by Salinity of Irrigation Water and Applied Nitrogen Levels. Indian Journal of Animal Nutrition 31:266271.

Singh, K.A. and Singh, L.N. (1992). Performance of oat varieties at midhills of Sikkim. Indian J. Hill Farm., 5: 133-134.

Zhou, X.; Jellen, E.N.; Murphy, J.P. (1999). "Progenitor germplasm of domesticated hexaploid oat". Crop science. $\quad 39$ : $\quad 1208-1214$. doi: $10.2135 /$ cropsci1999.0011183x00 3900040042x.

\section{How to cite this article:}

Gitam Singh, R.B. Sharma and Mahendra Singh. 2017. Green Fodder Production Potential of Oat cv. Kent under Semi-arid Climatic Conditions of Tonk-Rajasthan in Frontline Demonstration. Int.J.Curr.Microbiol.App.Sci. 6(3): 2228-2232. doi: http://doi.org/10.20546/ijcmas.2017.603.254 